\title{
A REVIEW ON PROCESS PARAMETERS OF VARIOUS PROCESS INTENSIFICATION TECHNIQUES FOR ETHYL ACETATE PRODUCTION
}

\author{
Ganesh N. Patil ${ }^{1,2, *}$ and Nirmala Gnanasundaram ${ }^{1}$ \\ ${ }^{1}$ School of Chemical Engineering, VIT University, Vellore, Tamilnadu 632014, India. \\ ${ }^{2}$ Mechanical and Industrial Engineering Department, College of Engineering, National \\ University of Science and Technology, Muscat, Oman. \\ *E-mail: ganeshpatil.nsk@gmail.com
}

\begin{abstract}
Ethyl acetate is intensively used as a solvent for paints, coatings, resins, inks, main ingredient in different fragrances and flavors for consumer products and decaffeination. An assessment of the ethyl acetate esterification process for different process intensification techniques was studied to identify the several advantages over the traditional process. Experimental and simulation details for individual ethyl acetate production process and coproduction process with n-butyl acetate or isopropyl acetate are discussed. Simulation studies analysis shows the comparison of various mathematical models and the identification of the most commonly used model for different process simulators. This review focuses on ethyl acetate process intensification techniques including Reactive distillation, pervaporation assisted reactive distillation, pressure-swing reactive distillation, reactive dividing wall columns, reactive extractive distillation, microwave reactive distillation, reactive chromatography. The effect of various process parameters i.e. ethanol flow rate, acetic acid flow rate, choice of a homogeneous and heterogeneous catalyst, reflux ratio, feed tray position, the total number of trays, types of entrainer, condenser and reboiler duties on ethyl acetate purity, overall production rate, energy consumption and total annual cost were discussed. Reactive distillation overcomes chemical equilibrium limitations, saving energy and ensuring economic effectiveness by reduced capital investment.
\end{abstract}

Keywords: Ethyl acetate, Reactive Distillation, Reactive Dividing Wall Column, Process Intensification

(C) RASĀYAN. All rights reserved

\section{INTRODUCTION}

Ethyl acetate (EA) is an important organic solvent widely used in various applications such as food and beverage, pharmaceutical, cosmetics, textiles, paints and coatings, adhesives and sealants, and others. One of the key issues in the production of acetates is the equilibrium limitation from the reversible reaction of acetic acid and alcohol. This motivates the use of reactive distillation (RD) to achieve high conversion.

Ethyl acetate is the most common ester of ethanol and acetic acid. Ethyl acetate is produced by three processes as given below:

1. Fischer Esterification Reaction process involves the reaction between ethanol and acetic acid, in the presence of an acid catalyst i.e. sulfuric acid, hydrochloride acid, or toluene sulfonic acid. The main drawbacks of this process include slow reaction rate and difficulty in separation of pure components due to the presence of azeotropic groups like ethanol-ethyl acetate-water, ethanol-water, water-acetic acid, ethyl acetate-ethanol, and ethyl acetate-water. ${ }^{1}$

$$
\mathrm{CH}_{3} \mathrm{COOH}+\mathrm{CH}_{3} \mathrm{CH}_{2} \mathrm{OH} \quad \longleftrightarrow \mathrm{CH}_{3} \mathrm{COOHCH}_{2} \mathrm{CH}_{3}+\mathrm{H} 2 \mathrm{O}+\Delta \mathrm{H}
$$

2. Dehydrogenation of ethanol is the cost-effective method as compared to the Fischer esterification. Dehydrogenation is carried out in a tubular reactor in the presence of copper or chromium catalyst. The main drawback of the process includes excess ethanol requirement and difficult separation due to hydrogen as a byproduct.

Rasayan J. Chem., 13(2), 920-933(2020)

http://dx.doi.org/10.31788/RJC.2020.1325640 
RASĀYAN J. Chem.

Vol. 13 | No. 2 |920 - 933| April - June | 2020

3. Tishchenko reaction process which is commonly used in Germany and Japan involves an organic chemical reaction that works on the principle of dismutation or disproportionation of an aldehyde. It is performed in the presence of a sodium or aluminium alkoxide catalyst, typically aluminium triethoxide. A disadvantage of this process includes the insufficient supply of acetaldehyde outside the petrochemical industries.

To overcome various inefficiencies of listed methods, many new technologies like improving production rate through process intensification process, switching to automation with artificial intelligence, enhancing plant performance through the internet of things (IoT) and assembling, maintaining and training with augmented reality are incorporated into the ethyl acetate industry.

In the Reactive Distillation (RD) process the reaction and separation processes take place in a single unit instead of two separate units. Thus production cost is reduced for RD compared to the traditional reactorseparator systems. Few advantages of the RD process include lower energy consumption, higher reactant conversion, low capital and operation cost. This article aims to study the effect of various reactive distillation process parameters on ethyl acetate production.

\section{Reactive Distillation}

Reactive Distillation (RD) is a process that combines chemical reaction with distillation in a single unit. In the reactive distillation unit, the reaction products are removed in time resulting in high reaction conversion. The heat released from the reaction can be used in the distillation process. RD has various advantages like higher conversion of the reactant for reversible reactions, improvement in the selectivity of the desired product, avoiding azeotropic conditions, and preventing the formation of undesired products and hot spots ${ }^{2,3}$. The major problems of the RD system are the removal of water formed during the esterification and separation of various azeotropes formed by ethyl acetate(EA), acetic acid (AA) and water.

Tang et al. proposed a process flow sheet for EA esterification reaction as shown in Fig.-1. In the proposed configuration a decanter was placed above the RD column to remove the water and the organic phase is passed through the stripper to remove the pure ethyl acetate. Top from the stripper recycled to the decanter. The dominant design variables identified for this process were feed ratio and number of trays in the rectifying section. ${ }^{4}$

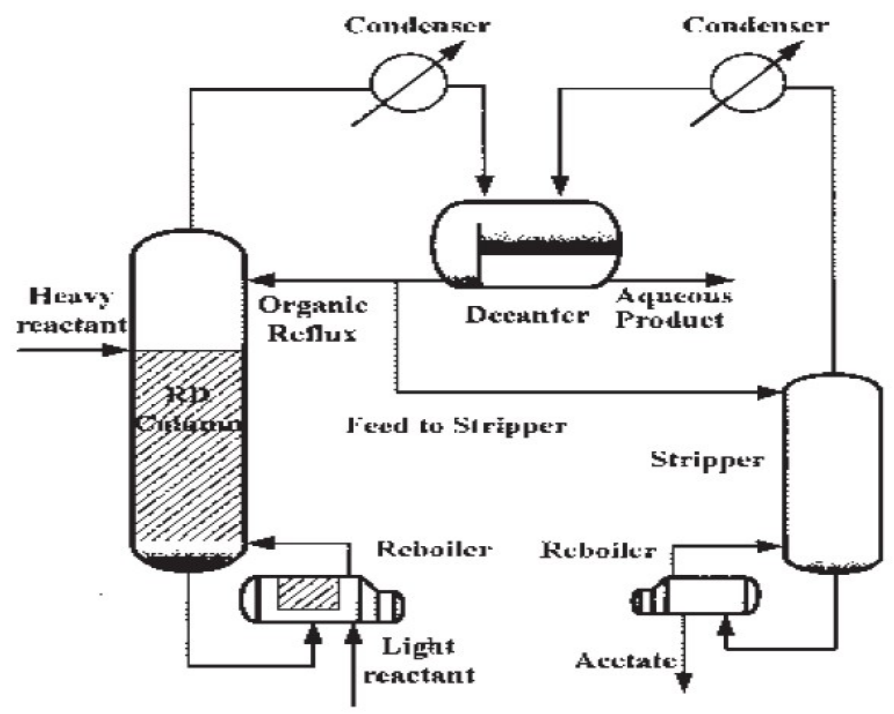

Fig.-1: Process Flow Sheet for EA Production ${ }^{4}$

Reddy et al. compared the energy requirement of reactive distillation and reactive chromatography (RC) for EA production. RC required less energy due to the complete conversion of ethanol but RD required more energy due to the high reflux ratio. A high reflux ratio was used to avoid the loss of acetic acid. ${ }^{5}$ 
RASĀYAN J. Chem.

Vol. 13 | No. 2 |920 - 933| April - June | 2020

Table-1: List of Azeotropes present in the Ethyl Acetate System ${ }^{5}$

\begin{tabular}{c|c|c|c|c|c}
\hline Components & $\mathrm{T}\left({ }^{\circ} \mathrm{C}\right)$ & Type of Azeotrope & \multicolumn{3}{|c}{ Composition } \\
\cline { 4 - 6 } & & & Ethyl Alcohol & Ethyl Acetate & Water \\
\hline EtOH-EA & 71.77 & Homogeneous & 0.448 & 0.552 & 0 \\
\hline EtOH-water & 78.14 & Homogeneous & 0.892 & 0 & 0.108 \\
\hline EA-water & 71.24 & Heterogeneous & 0 & 0.676 & 0.324 \\
\hline EtOH-EA-water & 70.45 & Homogeneous & 0.151 & 0.558 & 0.291 \\
\hline
\end{tabular}

$\mathrm{S}$. Hu et al. presented the relationship between reflux ratio and the number of theoretical stages for conventional and reactive distillation as shown in Fig.-2. The reflux ratio in the RD column was divided into two parts R1 and R2 as follows: (1) R1 was used for regular operation and can be reduced to $\mathrm{R}_{1 \mathrm{~min}}$ by increasing the theoretical stage number of RD column; (2) R2 was only used as an entrainer to carry the accumulated $\mathrm{H}_{2} \mathrm{O}$ out of the column. The value of $\mathrm{R} 2$ was constant and does not alter due to a change in the number of theoretical stages. The author suggested that reduction in R2 through process innovation and optimization can help to improve the process efficiency. ${ }^{6}$
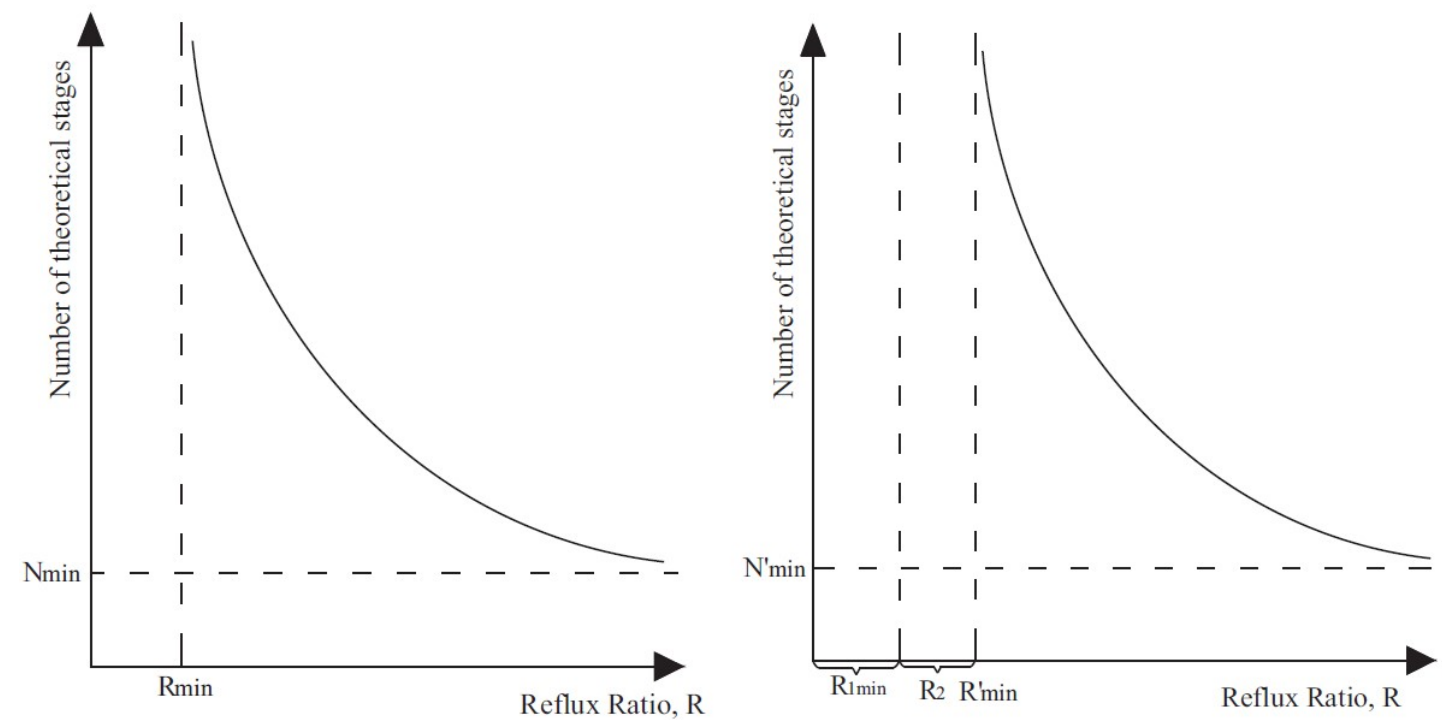

Fig.-2: Relationship between the Reflux Ratio and the Number of Theoretical Stages ${ }^{6}$

C. Li et al. discussed entrainer enhanced reactive distillation in esterification reaction to increase the relative volatility of water by forming a minimum heterogeneous azeotrope with water. The heterogeneous azeotrope distilled from the top of the column separates the product and water. Entrainer shifts chemical equilibrium, keeps the reaction section temperature below the thermal stability limit of the catalyst. Entrainer removes the water from the reaction section, improve the conversion, and increase the selectivity of the product. Entrainer volume and its volatility determine the temperature of the reaction section. ${ }^{[7-8]}$

Entrainer improves the conversion rate of the feedstock, increases the selectivity of the products in the reversible reaction, efficiently uses the raw materials and increases the process efficiency, provides more energy savings. ${ }^{6}$

S. Hu et al. studied various entrainers and presented experimental properties of entrainer liquids for EA production as shown in Table-2. After comparing the characteristics of all listed entrainers, the author suggested the NBA as the most appropriate entrainer. The advantages of using the NBA as an entrainer over others are discussed as follows. (1) the highest percentage of NBA was present in the five component system of the NBA-EA-EtOH-AA- $\mathrm{H}_{2} \mathrm{O}\left(126.01{ }^{\circ} \mathrm{C}\right)$, whereas the azeotropic temperatures for NBA- $\mathrm{H}_{2} \mathrm{O}$ and $\mathrm{EA}-\mathrm{H}_{2} \mathrm{O}$ was $91.01{ }^{\circ} \mathrm{C}$ and $70.37{ }^{\circ} \mathrm{C}$, respectively; (2) moles of water entrained by NBA was 5.18 times more than that by EA, and the solubility of NBA in water is less than that of EA in water; (3) the temperature gradient is about $108-112{ }^{\circ} \mathrm{C}(1 \mathrm{~atm})$, existed within the column makes the separation 
RASĀYAN J. Chem.

Vol. 13 | No. 2 |920 - 933| April - June | 2020

easier. The author developed the novel new process flow sheet with a side draw to the RD column. The stage number of the rectifying section and reactive section, side draw location and flow rate, side draw aqueous phase reflux flow rate, and the overhead organic reflux flow rate was investigated to determine an optimal flowsheet design. For similar capital investment, the new process shows $32 \%$ lower energy consumption. ${ }^{6}$

Table-2: Experimental Properties of the Entrainer Liquids ${ }^{6}$

\begin{tabular}{c|c|c|c|c|c}
\hline Component & $\begin{array}{c}\text { Normal } \\
\text { Boiling } \\
\text { Point }\end{array}$ & $\begin{array}{c}\text { Azeotropic } \\
\text { Temperature } \\
\left.\text { (with } \mathrm{H}_{2} \mathrm{O}\right)\end{array}$ & $\begin{array}{c}\text { Azeotropic } \\
\text { Composition }\left(\mathrm{H}_{2} \mathrm{O}\right)\end{array}$ & $\begin{array}{c}\text { Aqueous Phase } \\
\left(\mathrm{H}_{2} \mathrm{O}\right) \text { at } 40^{\circ} \mathrm{C}\end{array}$ & $\begin{array}{c}\text { Organic Phase } \\
\left(\mathrm{H}_{2} \mathrm{O}\right) \text { at } 40^{\circ} \mathrm{C}\end{array}$ \\
\hline Cyclohexane & 80.78 & 69.44 & 29.9 & $99.98 \%$ & $0.17 \%$ \\
\hline Benzene & 90.13 & 69.24 & 29.76 & $99.95 \%$ & $0.38 \%$ \\
\hline n-BA & 26.2 & 91 & 70.10 & $99.7 \%$ & $9.5 \%$ \\
\hline $\begin{array}{c}\text { Isobutyl } \\
\text { Acetate }\end{array}$ & 117.2 & 87.40 & 56.02 & $99.87 \%$ & $9.53 \%$ \\
\hline $\begin{array}{c}\text { Sec butyl } \\
\text { Acetate }\end{array}$ & 112.4 & 87 & 62.56 & $99.92 \%$ & $11.49 \%$ \\
\hline Amyl Acetate & 146 & 95.2 & 83.4 & - & \\
\hline
\end{tabular}

Lai et al. studied reactive distillation for the coproduction of ethyl acetate and isopropyl acetate. The effect of impure feed containing more water and excess cost to boil up water increased the total annual cost. Thus the TAC was less if the pure ethyl acetate feed is used. Control strategies for reactive distillation were studied with two control structures, dual-temperature control and one-temperature-onecomposition control. Three disturbances, feed flow, acid feed purity, and alcohol feed composition, were introduced to assess control performance using dual-temperature control and one-temperature-onecomposition control. The results showed that the TAC increase by a factor of 5\% for EA production using reactive distillation. Simulation results show good control performance for reactive distillation with azeotropic feeds. ${ }^{8}$

Tavan et al. studied hydration of ethylene oxide for ethyl acetate production. For minimum energy demand suggested optimum ethylene oxide and ethanol flow rate were $0.45 \mathrm{~mol} /$. Optimum reflux ratio for pure EA was identified as 3.5. Simulation results of RD show less energy requirement for the ethanol rate, the ethylene oxide rate and reflux ratio optimum values as compared to the conventional process. The proposed ethyl acetate RD process showed high esterification conversion, pure products, reduction in the equipment costs and required energy. ${ }^{9}$

Tian et al. proposed a co-production process for ethyl acetate and n-butyl acetate using Reactive Distillation Column. The effect of feed molar ratio of ethanol to n-butanol on energy saving was studied. Total annual costs of individual and coproduction processes were compared and the result shows that the coproduction process cost for a similar capacity of ethyl acetate was less. When the feed molar ratio of ethanol to n-butanol was less than 1.0, similar product purities were obtained as that with the individual technologies. The energy-savings increases slightly as the feed molar ratio of ethanol to n-butanol decreases. Compared with the individual technologies, the coproduction technology can save $20.40 \%$ energy when the feed molar ratio of ethanol to n-butanol was $0.5 .^{10}$

$\mathrm{He}$ et al. proposed green catalyst 1-sulfobutyl-3-methylimidazolium hydrogen sulfate ([HSO3bmim][HSO4]) for ethyl acetate production. Optimum catalyst dose of $0.203 \mathrm{~mol} / \mathrm{L}$ was selected based on simulation results and equipment cost. It was found that a higher number of theoretical plates in the rectifying section give high purity ethyl acetate and hence 7 plates in the rectifying section were selected. When the reflux ratio was high, distillate composition was close to azeotrope result in the increase of unreacted ethanol content. For the high purity of ethyl acetate, optimum reflux suggested value was 2 . Reactant reacts faster for small tray hold up, for the increase of holdup purity of product increases and thus $0.04 \mathrm{~L}$ tray holdup was identified. Fed tray location was suggested as the first plate over reboiler at the bottom. It was found that ethanol being the lightest component added at the lower feed tray increases the reactive section length. Simulation results provide $98.94 \mathrm{wt} \%$ of ethyl acetate and $91.51 \%$ of ethanol conversion. Used Green catalyst was superior to Amberlyst 15 for similar conversion and reaction rate. ${ }^{11}$ Fernandez et al. did a series of experiments ethyl acetate production in a reactive distillation pilot column. 
RASĀYAN J. Chem.

Vol. 13 | No. 2 |920 - 933| April - June | 2020

The effect of excess ethanol feed and stoichiometric feed configuration was studied in the presence of an acidic Ion-exchange resin heterogeneous catalyst. The authors developed a new dynamic model based on experimental results. The increase of reflux ratio increased the distillate flow rate and decrease of water content. The increase of ethanol flow rate resulted in higher ethanol conversion and reduction is acetic acid. $^{12}$

Singh et al. did a simulation study on homogenously catalyzed esterification reaction for EA production. EQ model and Aspen Plus model simulation results were compared for similar kinetic and process parameter values. The reaction rates reported for EQ models were five times higher than the rate based mode during the 34-37 reaction stage. The effect of the tray of product purity was studied and found that the product purity remains the same if the trays reduced from 48 to 42 in the upper section of the column. Shifting the feed stage location from 39 to 33 stages improved the ethanol conversion rate. The ethanol reaction rate increased by an additional ethanol feed at the bottom stage. ${ }^{13}$

Giwa et al. did simulation and economic comparison study for conventional and reactive distillation process based on higher purity of ethyl acetate, capital and operating cost. Simulation and economic analysis were done by using Aspen plus. Simulation data were presented for similar input conditions and the result shows benefits of the RD method over the conventional method for EA production. ${ }^{14}$

Wang et al. studied the effect of heat integration to reduce the production cost of EA. Alternative configurations designs i.e. two configurations with three columns and one configuration with two columns were studied for the heat integration/coupling process as follows. (1) Separation of ethanol/ethylacetate mixtures by using pressure-swing distillation. (2) RD column followed by a conventional distillation column operated at high pressure. (3) Reactive distillation and extractive distillation coupled with Heat integration and thermal coupling technologies for energy reduction. It was identified that the Reactive distillation and extractive distillation column coupled with heat integration provides high-purity ethyl acetate for lower annual $\operatorname{cost}^{15}$.

Calvar et al. compare the results for ethyl acetate production in RD by using acetic acid as a homogeneous catalyst and Amberlyst 15 as a heterogeneous catalyst. The esterification reactions were carried out between 303.15 and $353.15 \mathrm{~K}$ temperatures and different reactant compositions. $\mathrm{T}$ was seen that the purity of ethyl acetate depends on the azeotrope composition. Two different setups were studied as follows. (1) Feed was introduced into the column as a mixture of reactants: Ethanol feed introduced into the upper part of the catalyst with excess acetic acid provides higher EA (2) Reactants Ethanol and acetic acid added separately and found provides lower EA production than previous setup ${ }^{16}$.

Giwa et al. investigated the effects of property models on the qualities of the desired products obtained from reactive distillation processes in Aspen Plus. Packed type distillation column with 25 segments including the condenser and the reboiler is used during the study for the coproduction of EA and NBA. Fourteen different models were studied, the highest mole fractions of EA and NBA was obtained for the Wilson model and Peng-Robinson equation of state model. ${ }^{17}$

Park et al. did experimental and simulation study for the production of EA by using reactive distillation. The experimental setup consists of a distillation tower with 10 catalyst-packed plates, five separation trays above the catalyst packed plates, and three separation trays below the catalyst packed plates. EA purity obtained was $70 \%$ and further distillation gives $98 \%$ for optimum reflux ratio, feed flow rate of acetic acid and ethanol. ${ }^{18}$

Andrew et al. did a simulation study for the production of EA by RD using chemcad simulator. Effects of reflux ratio, distillate rate, feed tray location and activity model on the composition of ethyl were studied. The optimum composition of ethyl acetate was obtained for when acetic acid fed to the second tray and ethanol was added on the twelfth tray for a reflux ratio of 12. Ziegler-Nichols (ZN) tuning method was used for pressure control. By manipulating the flow rate of steam, reboiler pressure control can be adjusted. Manipulating Condenser heat duty was used to control of the purity of ethyl acetate. ${ }^{19}$

A summary of reactive distillation types of study with various catalysts, simulation models including simulator details and process parameters studied by various researchers are presented In Table-3.

\section{Reactive Distillation Pervaporation Hybrid Process}

Lee et al. proposed reactive distillation pervaporation (RD-PV) hybrid configuration where a side stream was removed from the rectifying section. Membrane pervaporation unit used to extract ethyl acetate from 
RASĀYAN J. Chem.

Vol. 13 | No. 2 |920 - 933| April - June | 2020

the side stream. The process had a 13\% energy saving as compared to the conventional two-column (RD and stripper) process. The author studied two temperature control strategies - single point and dual points and proposed the dual temperature control strategy due to its advantages to handling throughput and feed composition disturbances ${ }^{20}$.

Table 3: Summary of Reactive Distillation Simulation and Other Process Parameters for EA Production

\begin{tabular}{|c|c|c|c|c|c|}
\hline S. No. & Type of Study & Catalyst & $\begin{array}{l}\text { Thermodynamic } \\
\text { Model }\end{array}$ & $\begin{array}{ll}\text { Process } & \text { Parameters } \\
\text { Studied } & \end{array}$ & Ref. \\
\hline 1 & $\begin{array}{l}\text { Simulation } \\
\text { (Aspen Hysis) }\end{array}$ & Sulfuric acid & NRTL & $\begin{array}{l}\text { Effect of ethanol low rate, } \\
\text { Ethylene oxide flow rate } \\
\text { and Reflux ratio on } \\
\text { temperature and } \\
\text { component compositions } \\
\text { in RD column. }\end{array}$ & 9 \\
\hline 2 & $\begin{array}{l}\text { Simulation } \\
\text { (Aspen Plus 11.1) }\end{array}$ & Amberlyst 36 & $\begin{array}{l}\text { RADFRAC } \\
\text { (For VLE data) } \\
\text { NRTL (For n- } \\
\text { butyl acetate) } \\
\text { UNIQUAC (For } \\
\text { ethyl acetate) }\end{array}$ & $\begin{array}{l}\text { Effect of feed molar ratio } \\
\text { of ethanol to n-butanol on } \\
\text { product purities and } \\
\text { energy consumption }\end{array}$ & 10 \\
\hline 3 & $\begin{array}{l}\text { Experimental and } \\
\text { Simulation } \\
\text { (Aspen Plus V } \\
8.4 \text { ) }\end{array}$ & $\begin{array}{l}\text { 1-Sulfobutyl-3- } \\
\text { methylimidazolium } \\
\text { hydrogen sulfate }\end{array}$ & RADFRAC & 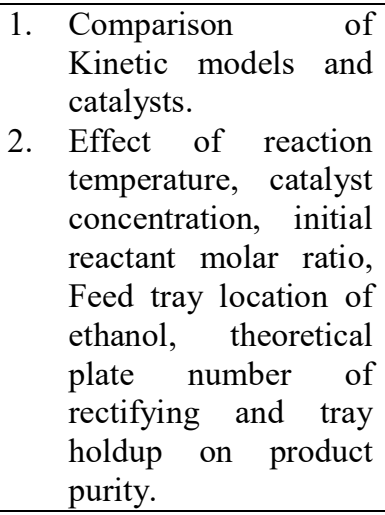 & 11 \\
\hline 4 & $\begin{array}{l}\text { Experimental and } \\
\text { Simulation } \\
\text { (Aspen Plus 11.1) }\end{array}$ & Amberlyst 36 & $\begin{array}{l}\text { RADFRAC } \\
\text { (For VLE data) } \\
\text { NRTL (For n- } \\
\text { butyl acetate) } \\
\text { UNIQUAC (For } \\
\text { ethyl acetate) }\end{array}$ & $\begin{array}{l}\text { Effect of ethanol feed } \\
\text { location, acetic acid feed } \\
\text { location, feed stage of the } \\
\text { reaction mixture of acetic } \\
\text { acid and n-butanol, reflux } \\
\text { ratio of ethyl acetate } \\
\text { reactive distillation } \\
\text { column, and distillate to } \\
\text { feed ratio of n-butyl } \\
\text { acetate column, on the } \\
\text { ethanol/n-butanol } \\
\text { conversions, } \\
\text { acetate/n-butyl acetate } \\
\text { purity, and energy } \\
\text { consumption. }\end{array}$ & 21 \\
\hline 5 & $\begin{array}{l}\text { Experimental and } \\
\text { Simulation }\end{array}$ & $\begin{array}{l}\text { Acidic } \\
\text { ion-exchange resin }\end{array}$ & NRTL & 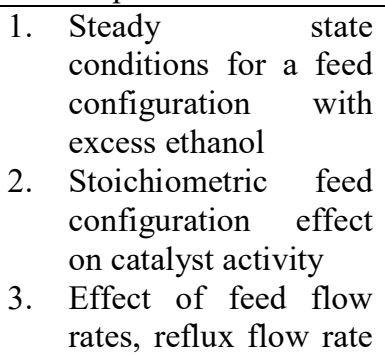 & 12 \\
\hline
\end{tabular}


RASĀYAN J. Chem.

Vol. 13 | No. 2 |920 - 933| April - June | 2020

\begin{tabular}{|c|c|c|c|c|c|}
\hline & & & & and heat duty & \\
\hline 6 & $\begin{array}{l}\text { Simulation } \\
\text { (Aspen Plus) }\end{array}$ & $\begin{array}{l}\text { Para-toluene- } \\
\text { sulfonic acid }\end{array}$ & NRTL & $\begin{array}{l}\text { 1. } \begin{array}{l}\text { Comparison of EQ } \\
\text { and rate-based models } \\
\text { in Aspen Plus }\end{array} \\
\text { 2. Effect of number of } \\
\text { stages on product } \\
\text { purity } \\
\text { 3. Effect of feed stage } \\
\text { location on ethanol } \\
\text { conversion } \\
\text { 4. The combined effect } \\
\text { of feed location and } \\
\text { the addition of } \\
\text { fresh ethanol on heat } \\
\text { duty }\end{array}$ & 13 \\
\hline 7 & $\begin{array}{l}\text { Experimental and } \\
\text { Simulation } \\
\text { (Aspen Plus) }\end{array}$ & Amberlyst 35 & - & $\begin{array}{l}\text { 1. Experimental } \\
\text { runs for Type II } \\
\text { RD Process } \\
2 . \text { Study the } \\
\text { initial charges to } \\
\text { the column } \\
\text { holdups and a } \\
\text { start-up } \\
\text { procedure for } \\
\text { continuous } \\
\text { production }\end{array}$ & 22 \\
\hline 8 & $\begin{array}{l}\text { Simulation } \\
\text { (Aspen Plus) }\end{array}$ & $\begin{array}{l}\text { Sulfuric Acid } \\
\text { Purolite CT179 }\end{array}$ & $\begin{array}{l}\text { RADFRAC } \\
\text { NRTL }\end{array}$ & $\begin{array}{l}\text { Comparison of catalyst } \\
\text { cost, capital investment } \\
\text { cost and energy cost, } \\
\text { reaction rate, number of } \\
\text { trays for homogeneous } \\
\text { and heterogeneous } \\
\text { catalytic processes. }\end{array}$ & 23 \\
\hline 9 & $\begin{array}{l}\text { Simulation } \\
\text { (Aspen Plus) }\end{array}$ & NA & UNIQUAC & $\begin{array}{lr}\text { Comparison } & \text { of } \\
\text { conventional and } & \text { RD } \\
\text { processes based on } \\
\text { product purity, total } \\
\text { annual cost, operating } \\
\text { cost, equipment and utility } \\
\text { cost and installed cost. }\end{array}$ & 14 \\
\hline 10 & $\begin{array}{l}\text { Simulation } \\
\text { (ChemCad) }\end{array}$ & $\begin{array}{l}\text { Potassium } \\
\text { butanolate }\end{array}$ & NRTL & $\begin{array}{l}\text { 1. RD column top } \\
\text { mixture (Ethanol + } \\
\text { Ethyl acetate) } \\
\text { separation by } \\
\text { Extractive } \\
\text { Distillation, Pressure } \\
\text { Swing Distillation } \\
\text { and Convectional } \\
\text { distillation and to } \\
\text { calculate annual cost }\end{array}$ & 15 \\
\hline
\end{tabular}


RASĀYAN J. Chem.

Vol. 13 | No. 2 |920 - 933| April - June | 2020

\begin{tabular}{|c|c|c|c|c|c|}
\hline & & & & $\begin{array}{l}\text { for each method. } \\
\text { 2. Study of Heat } \\
\text { integration and } \\
\text { thermal coupling } \\
\text { between two columns. }\end{array}$ & \\
\hline 11 & $\begin{array}{l}\text { Simulation } \\
\text { (Aspen Plus) }\end{array}$ & Sulfuric acid & NRTL & $\begin{array}{l}\text { Comparison of two basic } \\
\text { control schemes and } \\
\text { development of a new } \\
\text { control scheme }\end{array}$ & 24 \\
\hline 12 & $\begin{array}{l}\text { Simulation } \\
\text { (Aspen Plus) }\end{array}$ & Sulfuric acid & NRTL & $\begin{array}{l}\text { Design of an ethyl acetate } \\
\text { system to find optimum } \\
\text { operating conditions to } \\
\text { minimize the total } \\
\text { operating cost. }\end{array}$ & 25 \\
\hline 13 & $\begin{array}{l}\text { Simulation } \\
\text { (Aspen Plus) }\end{array}$ & $\begin{array}{lr}\text { Purolite } & \text { CT179 } \\
\text { (For } & \text { EA) } \\
\text { Amberlyst } & 15 \text { (For } \\
\text { IPAc) } & \end{array}$ & NRTL & $\begin{array}{l}\text { Effects of reactant purity } \\
\text { on the design and control } \\
\text { of reactive distillation }\end{array}$ & 8 \\
\hline 14 & $\begin{array}{l}\text { Experimental and } \\
\text { Simulation }\end{array}$ & Amberlyst 15 & UNIQUAC & $\begin{array}{l}\text { Effect of feed composition } \\
\text { and reflux ratio }\end{array}$ & 16 \\
\hline 15 & $\begin{array}{l}\text { Simulation } \\
\text { (Aspen Plus) }\end{array}$ & NA & $\begin{array}{l}14 \text { Different } \\
\text { models }\end{array}$ & 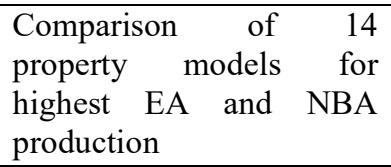 & 17 \\
\hline 16 & $\begin{array}{l}\text { Simulation } \\
\text { (Aspen Plus) }\end{array}$ & $\begin{array}{l}\text { Sulfuric Acid } \\
\text { Purolite CT179 }\end{array}$ & RADFRAC & $\begin{array}{l}\text { Comparison of three } \\
\text { process flowsheets to } \\
\text { optimize the quantitative } \\
\text { design based on Total } \\
\text { annual cost }\end{array}$ & 4 \\
\hline 17 & $\begin{array}{l}\text { Experimental and } \\
\text { Simulation }\end{array}$ & Amberlyst-15 & NRTL & $\begin{array}{l}\text { Experimental study for a } \\
\text { fixed number of catalyst } \\
\text { packed trays on ethyl } \\
\text { acetate concentration }\end{array}$ & 18 \\
\hline 18 & $\begin{array}{l}\text { Simulation } \\
\text { (Chemcad) }\end{array}$ & Sulfuric acid & NRTL & $\begin{array}{l}\text { Effect of reflux ratio, } \\
\text { distillate rate, feed tray } \\
\text { location and activity } \\
\text { model on ethyl acetate } \\
\text { composition }\end{array}$ & 19 \\
\hline 19 & $\begin{array}{l}\text { Simulation } \\
\text { (Chemcad) }\end{array}$ & Sulfuric acid & NRTL & $\begin{array}{l}\text { Effect of pressure, reflux } \\
\text { ratio, feed stage location, } \\
\text { excess reactants on the } \\
\text { reactants conversion and } \\
\text { the ethyl } \\
\text { acetate production }\end{array}$ & 26 \\
\hline
\end{tabular}

Hasanoglu et al. did the experimental study for esterification of ethyl acetate by using a batch pervaporation membrane reactor. Molar ratios of reactants and change of temperature with Polydimethylsiloxane membrane give higher conversion ${ }^{27}$. Vapor-liquid equilibrium calculations using the Wilson equation and data obtained by pervaporation were compared. The degree of swelling increases with ethyl acetate composition. An increase in temperature increases affinity between solve and polymer which in turn increases the degree of swelling in the membrane. The optimum temperature of 30-40 C was used for pervaporation separations by using Polydimethylsiloxane (PDMS) membranes. ${ }^{28}$ 
RASĀYAN J. Chem.

Vol. 13 | No. 2 |920 - 933| April - June | 2020

He et al. studied a membrane reactor with sulfonated polyethersulfone, polyethersulfone, non $\mathrm{H}$ woven fabrics composite catalytic coupled with a polyvinyl alcohol pervaporation membrane for ethyl acetate production in a flow-through mode. Single flow-through mode and closed-loop flow through methods were studied for the effect of temperature, ethanol to acetic acid molar ratio and residence time on ethanol to ethyl acetate conversion. Results show that pervaporation-assisted esterification in the closed-loop mode gives $95.4 \%$ conversion. ${ }^{29}$

Rathod et al. did a simulation study on esterification of acetic acid and ethanol using hydrophobic membranes and proposed a mathematical model. Experimental and model results for acetic acid conversion at $50{ }^{\circ} \mathrm{C}, 60{ }^{\circ} \mathrm{C}$ and $70{ }^{\circ} \mathrm{C}$ were compared. Simulation results were in good agreement with the experimental data. ${ }^{30}$

Zhang et al. did an experimental study on pervaporation of ethyl acetate by preparing the chitosan and polyvinyl pyrrolidine (PVP) blend membranes crosslinked with glutaraldehyde (GA). The pervaporation properties of the membranes were studied through dehydration of the ethyl acetate/ethanol/water azeotrope. An increase in GA content increases the separation factor and decreases the permeation flux. The addition of a certain amount of PVP enhances the hydrophilicity of the membranes. An increase in feed temperature increases permeation flux and reduces separation factor. ${ }^{31}$

Das et al. did the experimental investigation to increase ethyl acetate conversion by 2 types of crosslinked PVA membranes using maleic acid and citric acid as crosslinking agents. The water separation ability of the cross-linked membranes from aqueous acetic acid and ethanol solutions were tested by pervaporation. Separation factor and flux for PVAMA and PVACA membranes were studied for acetic acid-water and ethanol-water separation. Both membranes show high selectivity and permeating ability. Compare to conventional esterification $38 \%$ higher conversion of ethanol and acetic acid was obtained. ${ }^{32}$ Lv et al. did experimental studies and proposed a new energy-saving RD-PV process for ethyl acetate production as shown in Fig.-3. The composite membrane was prepared by coupling the PVA/ceramic with the RD reboiler. The effects of $\mathrm{PV}$ operating temperature and $\mathrm{AA}$ to ethanol molar ratio on the $\mathrm{RD}$ performance were studied. PVA/ceramic composite membrane shows good PV performance and stability with a given total flux and a separation factor of AA-water solution. Ethanol conversion and EA purity were increased from 82.4 to 85.6 weight $\%$ and from 81.3 to $84.8 \%$ respectively. ${ }^{33}$

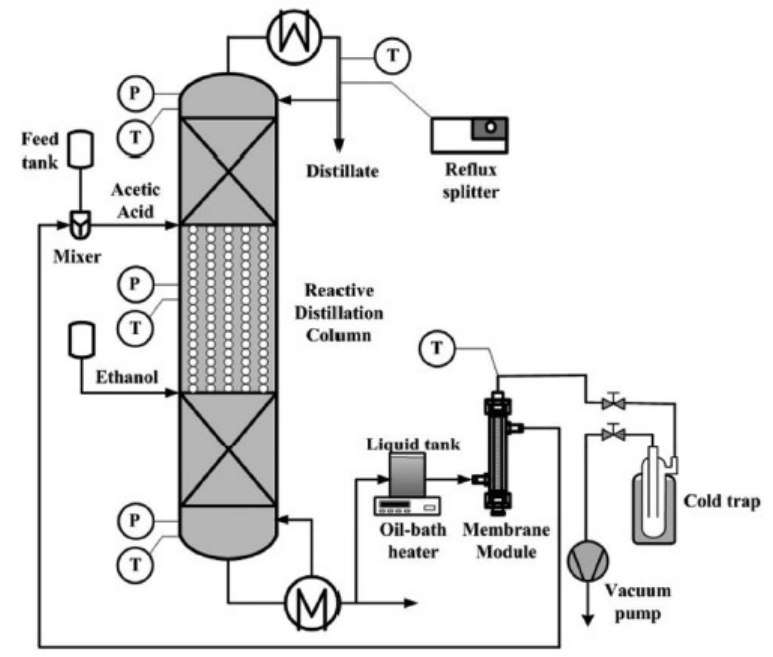

Fig.-3: Experimental Setup of RD-PV Process. ${ }^{33}$

\section{Pressure Swing Reactive Distillation}

Homogeneous azeotropic mixtures are separated by using pressure swing distillation (PSD). The PSD process uses the pressure sensitivity of the binary azeotropic point. An increase in pressure shifts azeotropic point to lower concentrations of the low boiling component. Thus at different pressures azeotropic mixture can be separated. 
RASĀYAN J. Chem.

Vol. 13 | No. 2 |920 - 933| April - June | 2020

Klein A. et al. discussed the advantages of the PSD process over the entrainer enhanced distillation process. PSD process required less number of stages for the recycling of the entrainer. For effective heat integration, the low-pressure column was heated by the heat of the condenser of the high-pressure column. Process control strategies development was found to be difficult due to more complex automation which makes PSD process more complex. ${ }^{34}$

\section{Reactive Dividing Wall Column (RDWC)}

$\mathrm{H}$. Li et al. studied the experiment and simulation of ethyl acetate and butyl acetate coproduction for two reactive dividing wall column structures. BA was used as an entrainer to remove the water generated by the two esterification reactions. It was found that the experimental results were in good agreement with the simulation results. Two types of RDWC structures RDWC-FC and RDWC-RS were proposed as shown in Fig.-4 and Fig.-5. The co-production process operating parameters such as the reflux ratio of the aqueous phase, reflux ratio of the vapor split, reflux ratio of liquid spilt of RDWC were optimized by using Aspen Plus. Optimal operating parameters for both types of RDWC were calculated. Energy-saving and TAC of RDWC were studied by comparing the RDWC-FC and RDWC-RS with traditional RD column. ${ }^{35}$

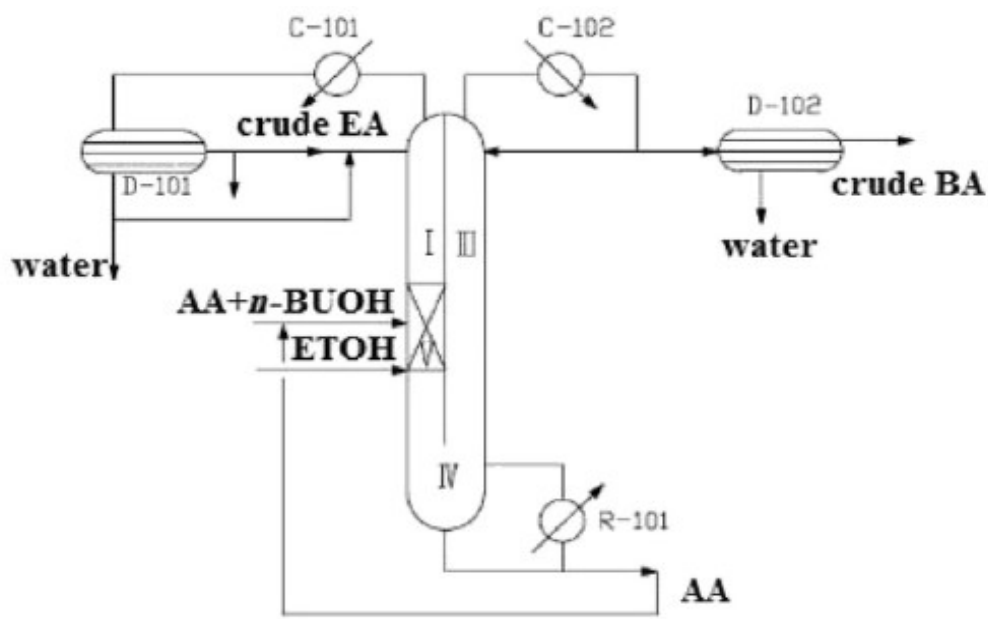

Fig.-4: The Process of RDWC-RS for Co-producing Ethyl Acetate and n-Butyl Acetate ${ }^{35}$

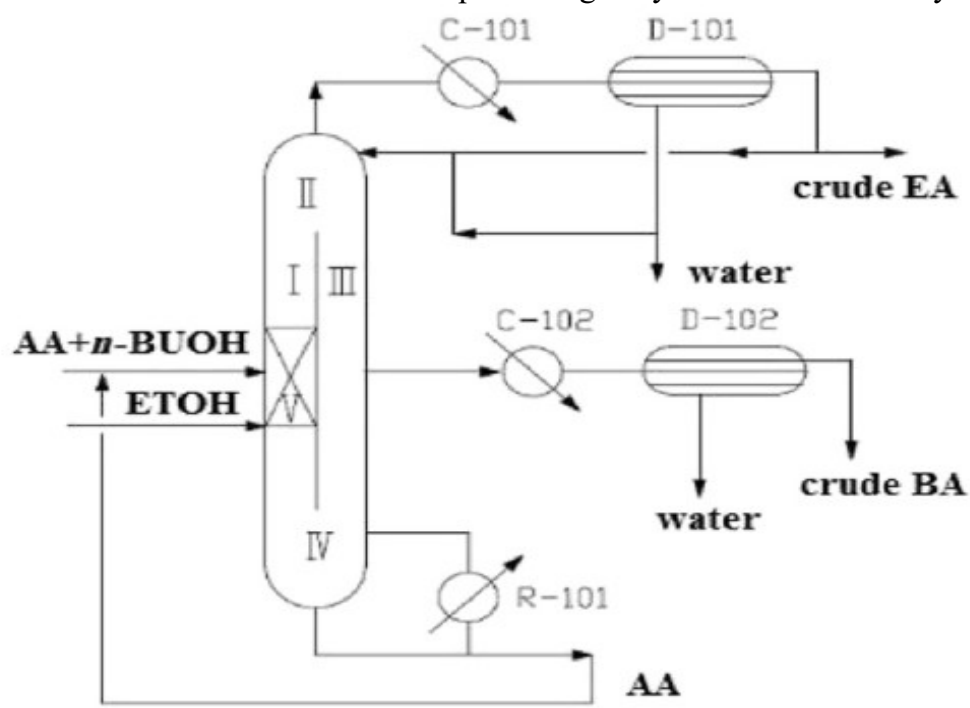

Fig.-5: The Process of RDWC-FC for Co-producing Ethyl Acetate and n-Butyl Acetate ${ }^{35}$

Xie et al. studied the experiments and simulations of the RDWC for the production of ethyl acetate. To avoid corrosion of the equipment caused by the acidity of the catalyst, heterogeneous catalysts Amberlyst 15 was added with a novel catalyst loading method. The reliability of the proposed simulation model was 
RASĀYAN J. Chem.

Vol. 13 | No. 2 |920 - 933| April - June | 2020

verified by the experimental study on the change of liquid split ratio and reflux ratio. The structural parameter height $(\mathrm{H})$ has an optimal value to achieve the optimal contact between the gas and liquid phase reactive section of the column. A comparison of economic analysis was conducted between the traditional RD column and RDWC. The results showed that RDWC can save $34.7 \%$ of total operating costs and $18.5 \%$ of TAC. ${ }^{36}$

Santaella et al. proposed three RDWC configurations. In the first configuration (Fig.-6a), due to continuous removal of water reduced the remixing effect into the reactive section resulted in higher conversions and energy savings. In the second configuration (Fig 6b) water was removed as a side stream, reduces ethyl acetate losses with an increase in the acetic acid losses results in lower conversions. Modified configuration (Fig. 6c) suggested removing water by using additional reboiler and additional bottoms stream, shown improved performance among the three configurations. ${ }^{37}$

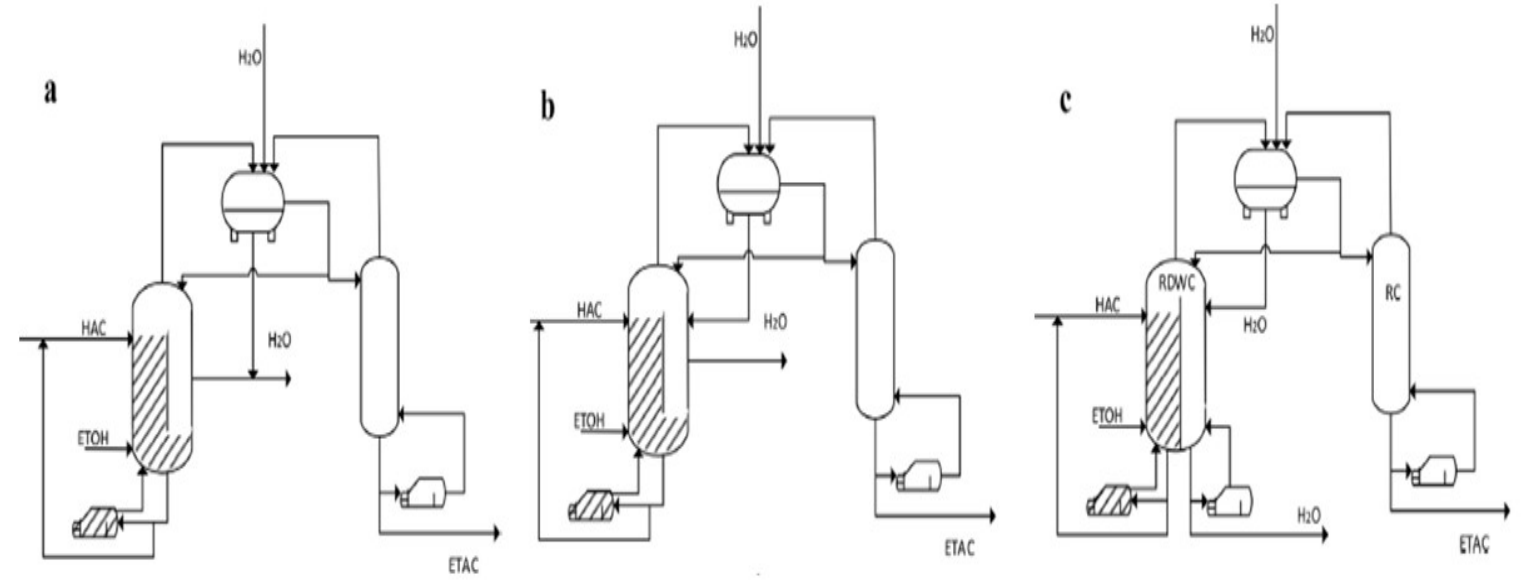

Fig.-6: Three Different Configurations of RDWC ${ }^{37}$

Safe et al. did the simulation study of EA production by RDWC shows the higher production by removing the water produced in the reaction from the system. The reaction-separation efficiency increased because the side stream extracts the water produced and the chemical equilibrium was displaced. By extracting water can achieve a higher amount of ethyl acetate compound produced as observed by the favorable modification of the equilibrium thermodynamic constant Simulation results show $27.6 \%$ improving in ethyl acetate purity comparing to reactive distillation in the same startup condition. ${ }^{38}$

Zhang et al. studied the simulation of extractive dividing wall column (EDWC) in a three-column system. EDWC was used to separate ethyl acetate and isopropyl alcohol using ethylene glycol as an entrainer. The objective of the study was to estimate total annual cost, study the effect of control variables i.e. entrainer flow rate and vapor split ratio on product purity, identification and comparison of various control structures. Best control temperatures locations were identified using sensitivity criterion and basic control structure was prepared. Based on control structure and sensitivity analysis two control structures were prepared which shows a smaller deviation and less settling time. Entrainer flow rate and vapor split ratio were adjusted to control the purity specifications. ${ }^{39}$

Xie et al. studied the coproduction of EA and NBA in RDWC. Effect of NBA as a entrainer was studied. The effects of Catalyst loading per stage, reflux ratio, liquid split ratio and molar feed ratio, ethyl acetate/n-butyl acetate purity, pressure drop and total energy consumption were investigated and the optimum result was presented. ${ }^{40}$

\section{Microwave Reactive Distillation (MRD)}

Ding et al. developed a laboratory-scale microwave reactive distillation setup as shown in Fig.-7. The acetic acid flow rate was kept at $2.5 \mathrm{ml} / \mathrm{min}$ for optimum EA production. With an increase in the reflux ratio up to 4 the EA content was increased drastically. An increase in Reboiler heating power initially increases the EA conversion but later it reduced the residence time of ethanol and reduces the EA 
RASĀYAN J. Chem.

Vol. 13 | No. 2 |920 - 933| April - June | 2020

conversion. Optimum heating power of $200 \mathrm{~W}$ was estimated for higher EA production. The operation time required for MRD process was less than $\mathrm{RD}$ process for similar energy requirements. Also, MRD process gives higher EA production than $\mathrm{RD}$ for the similar reflux ratio. ${ }^{41}$

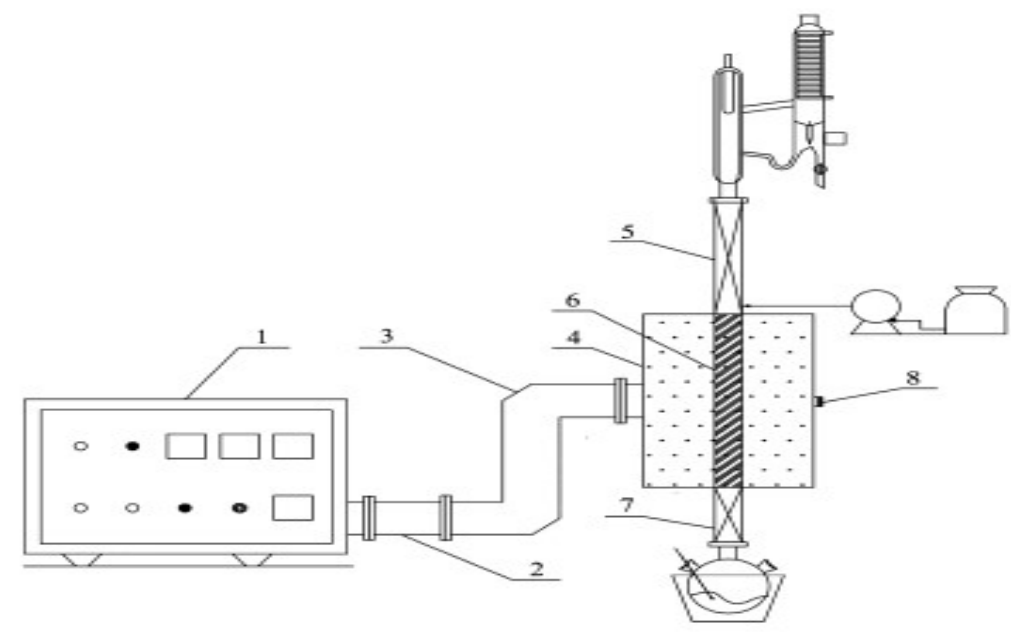

Fig.-7: Experiment Setup for MRD Process

(1:Microwave Generator, 2:Annular Water Load, 3: Rectangular Waveguide, 4: Microwave Cavity, 5:Rectification Section, 6:Reaction Section, 7:Stripping Section, 8:Infrared Thermometer Probe) ${ }^{41}$

\section{Reactive Chromatography}

Reddy et al. did a comparative simulation study of reactive chromatography (RC) and reactive distillation for the production of ethyl acetate. A simulated moving bed reactor (SMBR) was used for reactive chromatography experimental setup as shown in Fig.-8. RC can completely convert ethanol to EA and thus raffinate and extract phase were free from methanol. This reduces the energy requirement for the RC process. For RD, volatility differences are less and thus a high reflux ratio was required to avoid the loss of acetic acid from distillate which increases the energy requirement. There was a scope for suggested detailed cost estimation and pilot-scale studies for the production of ethyl acetate by RC. ${ }^{5}$

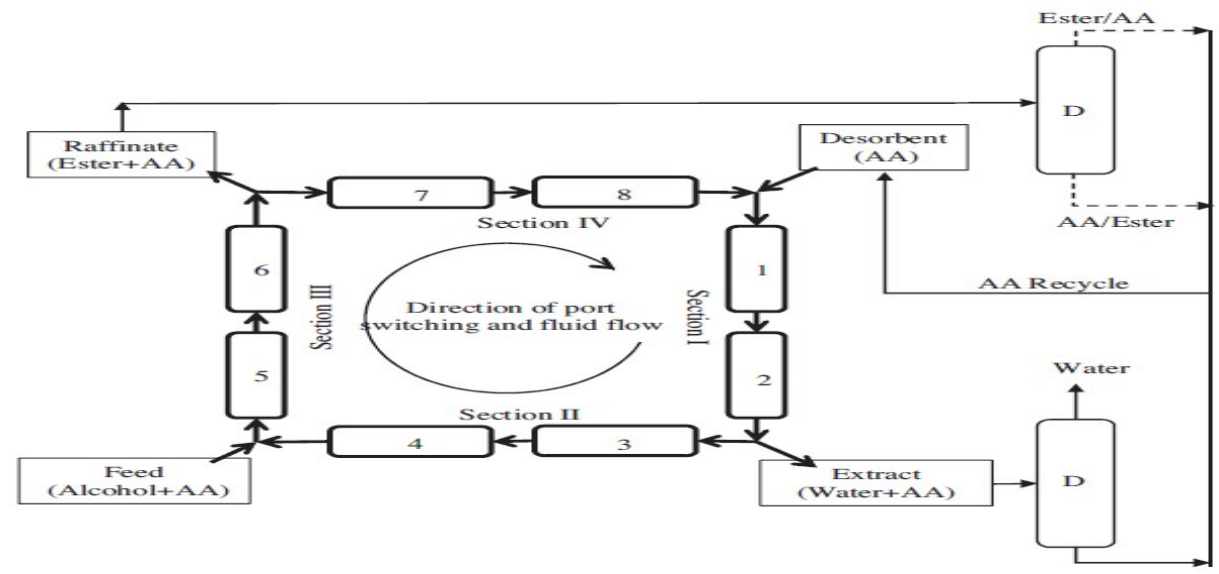

Fig.-8: Schematic of SMBR for the Equilibrium Reaction (Acetic acid (AA) + Alcohol = Ester + Water); Solvent is chosen as AA; D represents the Distillation Column. ${ }^{5}$

\section{CONCLUSION}

A review of various process intensification techniques used for ethyl acetate production has been carried out. Techniques including Reactive distillation, pervaporation coupled reactive distillation, pressure- 
RASĀYAN J. Chem.

Vol. 13 | No. 2 |920 - 933| April - June | 2020

swing reactive distillation, reactive dividing-wall columns, reactive extractive distillation, microwave reactive distillation, reactive chromatography, bubble-mediated reactive separation were studied for various configurations. Researchers discussed the effect of various process parameters i.e. ethanol flow rate, acetic acid flow rate, choice of a homogeneous and heterogeneous catalyst, reflux ratio, Feed tray position, the total number of trays, types of entrainer, condenser and reboiler duties on ethyl acetate purity, overall production rate, energy consumption and total annual cost were discussed in each process intensification method. The review shows that there are two most commonly used catalysts (sulfuric acid and Amberlyst 15) and NRTL thermodynamic model for simulation. There is sufficient data available for experimentation and simulation of Reactive distillation as compare to other methods. Lower annual cost and high energy saving will be possible in Reactive dividing wall column configuration as compared to other process intensification techniques.

\section{REFERENCES}

1. J. Otera, J. Nishikido, Wiley-VCH, 2, (2010), DOI:10.1002/3527601848.

2. J. A. Weinfeld, S. A. Owens, R. B. Eldridge, Chemical Engineering and Processing: Process Intensification, 123, 20(2018), DOI:10.1016/j.cep.2017.10.019.

3. J. Chin, J.W. Lee, J. Choe, AIChE Journal Process Systems Engineering, 52(5), 1790(2006), DOI: $10.1002 /$ aic. 10795.

4. Y. T. Tang, Y. W. Chen, H. P. Huang, C. C. Yu, S. B. Hung, M. J. Lee, AIChE Journal Process Systems Engineering, 51(6), 1683(2005), DOI:10.1002/aic.10519.

5. B. Reddy, R. Bhat, A. Agrawal, P. Patidar, S. Mahajani, Chemical Engineering \& Processing: Process Intensificatio, 95, 17(2015), DOI:10.1016/j.cep.2015.05.006.

6. S. Hu, B. J. Zhang, X.Q. Hou, D. L. Li, Q. L. Chen, Chemical Engineering and Processing: Process Intensificatio, 50(11-12), 1252 (2011), DOI:10.1016/j.cep.2011.07.012.

7. C. Li, C. Duan, J. Fang, H. Li, Chinese Journal of Chemical Engineering, 27(6), 1307(2018), DOI:10.1016/j.cjche.2018.10.007.

8. I. K. Lai, S. B. Hung,W. J. Hung, C. C. Yua, M. J. Lee, H. P. Huang, Chemical Engineering Science, 62(3), 878(2007),DOI:10.1016/j.ces.2006.10.019.

9. Y. Tavan, R. Mosayebi, S. Hossein, Chemical Engineering and Processing: Process Intensification, 73, 81(2013), DOI:10.1016/j.cep.2013.05.015.

10. H. Tian, H. Zheng, Z. Huang, T. Qiu, Y. Wu, Industrial and Engineering Chemistry Research, 51(15), 5535(2012), DOI:10.1021/ie202154x.

11. R. He, Y. Zou, Y. Dong, Y. Muhammad, S. Subhan, Z. Tong, Chemical Engineering Research and Design, 137, 235-245 (2018), DOI:10.1016/j.cherd.2018.07.020

12. M. F. Fernandez, B. Barrosof, X. Meyer, M. Meyer, M. V. L. Lann, G. C. L. Roux, M. Brehelin, Chemical Engineering Research and Design, 91(12), 2309(2013), DOI:10.1016/j.cherd.2013.05.013.

13. D. Singh, R. K. Gupta, V. Kumar, Chemical Engineering Communications, 207(1), 109(2019), DOI: $10.1080 / 00986445.2019 .1574766$.

14. A. Giwa, S. O. Giwa, International Journal of Engineering Research \& Technology (IJERT), 2(8), 594(2013).

15. S. J. Wang, H. P. Huang, C. C. Yu, Industrial and Engineering Chemistry Research, 49(2), 750(2010), DOI:10.1021/ie901413c.

16. N. Calvar, B. Gonzalez, A. Dominguez, Chemical Engineering and Processing: Process Intensification, 46(12), 1317(2007), DOI:10.1016/j.cep.2006.10.007

17. S. O. Giwa, International Journal of Advanced Scientific and Technical Research, 3(1), 466(2013).

18. J. Park, N. Lee, S. Park, J. Cho, Industrial and Engineering Chemistry Research, 12(4), 516(2006).

19. A. N. Amenaghawon, S. E. Ogbeide, Journal of Engineering and Applied Sciences, 4, 16(2012).

20. H. Tian, S. Zhao, H. Zheng, Z. Huang, Chinese Journal of Chemical Engineering, 23(4), 667(2015), DOI: $10.1016 /$ j.cjche.2014.12.007

21. I. K. Lai, Y.C. Liu, C. C. Yu, M. J. Lee, H. P. Huang, Chemical Engineering and Processing: Process Intensification, 47(9-10), 1831(2008), DOI:10.3182/20070606-3-MX-2915.00062.

22. H. Y. Lee, H. P. Huang, I. L. Chien, Computer Aided Chemical Engineering, 21, 1045(2006), 
RASĀYAN J. Chem.

Vol. 13 | No. 2 |920 - 933| April - June | 2020

DOI: 10.1016/S1570-7946(06)80184-7.

23. H. Y. Lee, H. P. Huang, I. L. Chien, Journal of process control, 17(4), 363(2007), DOI: 10.1016/j.jprocont.2006.10.002.

24. Y. T. Tang, H. P. Huang, I. L. Chien, Computer Aided Chemical Engineering, 15, 1044 (2003), DOI: 10.1016/S1570-7946(03)80446-7.

25. C. Chilev, E. Simeonov, Journal of Chemical Technology and Metallurgy, 52(3), 463(2017).

26. H. Lee, S. Li, C. Chen, Industrial and Engineering Chemistry Research, 55(32), 8802(2016), DOI:10.1021/acs.iecr.6b01358.

27. A. Hasanoglu, Y.Salt, S. Keleser, S. Dincer, Desalination, 245(1), 662(2009), DOI:10.1016/j.desal.2009.02.034.

28. A. Hasanoglu, Y.Salt, S. Keleser, S. Ozkan, S. Dincer, Chemical Engineering and Processing: Process Intensification, 44(3), 375(2005), DOI:10.1016/j.cep.2004.06.001.

29. S. Guo, B. He, J. Li, Q. Zhao, Y. Cheng, Chemical Engineering and Technology, 37(3), 478 (2014), DOI: $10.1002 /$ ceat.201300467.

30. A. P. Rathod, K. L. Wasewar, and S. S. Sonawane, 3rd International Conference on Biology, Environment and Chemistry,IACSIT Press, Singapore, 46(19), (2012), DOI:10.7763/IPCBEE. 2012. V46. 19.

31. X. H. Zhang, Q.L. Liu, Y. Xiong. A. M. Zhu, Y. Chen, Q. G. Zhang, Journal of Membrane Science, 327(1-2), 274(2009), DOI:10.1016/j.memsci.2008.11.034.

32. S. Das, A. K. Banthia, B. Adhikari, Indian Journal of Chemical Technology, 14, 552(2007).

33. B. Lv, G. Liu, X. Dong, W. Wei, W. Jin, Industrial and Engineering Chemistry Research, 51(23), 8079(2012), DOI:10.1021/ie3004072.

34. A. Klein, Process Sciences the Technical University of Berlin, Berlin, Retrieved from https://dnb.info/990851729/34

35. H. Li, T. Li, C. Li, J. Fang, L. Dong, Chinese Journal of Chemical Engineering, 27(1), 136 (2019), DOI: 10.1016/j.cjche.2018.02.023.

36. J. Xie, , C. Li, F. Peng, L. Dong, S. Ma, Chinese Journal of Chemical Engineering, 26(7), 1468(2018), DOI:10.1016/j.cjche.2018.01.021.

37. M. A. Santaella, A. Orjuela, P. C. Narvaez, Chemical Engineering and Processing: Process Intensification, 96, 1(2015), DOI:10.1016/j.cep.2015.07.027.

38. M. Safe, A. H. Jahanmiri1, S. M. Khazraee, $6^{\text {th }}$ International Chemical Engineering Congress and Exhibition(ICHEC, Iran (2009).

39. H. Zhang, Q. Ye, J. Qin, H. Xu, N. Li, Industrial and Engineering Chemistry Researc, 53(3), 1189(2014), DOI: 10.1021/ie403618f.

40. J. Xie, F. Peng, C. Li, T. Jiang, S. Ma, Chemical Engineering Technology, 41(9), 1808(2018), DOI: $10.1002 /$ ceat.201700640.

41. H. Ding, M. Liu, Y. Gao, J. Qi, H. Zhou, J. Li, Industrial and Engineering Chemistry Research, 55(6), 1590(2016), DOI:10.1021/acs.iecr.5b00893

[RJC-5640/2019] 